\title{
Monitoring, Moral Hazard, and Market Power: a Model of Bank Lending
}

Daniel Covitz and Erik Heitfield ${ }^{1}$

August 5, 1999

${ }^{1}$ We thank Robert Avery, Alan Berger, Diana Hancock, Tim Hannan, Beth Kiser, Myron Kwast, and Robin Prager for their valuable comments. The analysis and conclusions set forth are those of the authors and do not reflect the views of the Federal Reserve Board staff or the Board of Governors. 


\begin{abstract}
We model the relationship between market power and both loan interest rates and bank risk without placing strong restrictions on the moral hazard problems between borrowers and banks, and between banks and a government guarantor. Our results suggest that these relationships hinge on intuitive parameterizations of the overlapping moral hazard problems. Surprisingly, for lending markets with a high degree of borrower moral hazard, but limited bank moral hazard, we find that banks with market power charge lower interest rates than competitive banks. We also find that competition makes banking industry risk highly sensitive to macroeconomic fluctuations by making banks more vulnerable to borrower moral hazard. This finding offers an explanation for the dramatic rise and subsequent decline in bank failure rates during the 1980s and 1990s.
\end{abstract}


Under [the heightened competition of the 1980s], many banks adopted riskier loan policies in an attempt to increase revenue and to maintain market share vis-a-vis other lending institutions. Both examiners and commercial bankers themselves who were familiar with the issues of that time suggested that banks had increased difficulty coping with the new environment and that many conservatively managed institutions assumed greater risks because of the general belief that "if we don't make the loan, the institution across the street will."

- Federal Deposit Insurance Corporation

History of the 1980s - Lessons for the Future

\section{Introduction}

The ten years from 1983 to 1992 were by far the United States banking industry's worst since the Great Depression. During that time 1,501 federally insured commercial banks holding $\$ 236$ billion in real deposits failed. To put these numbers in perspective, only 230 banks holding $\$ 45$ billion in real deposits failed during the 35 years prior to $1983 .^{1}$ Though no single phenomenon can fully explain this dramatic surge in bank insolvency, as the quotation above shows, commentators within the industry have cited increased competition among banks and between banks and other lending institutions as an important contributing factor. In this view, vigorous competition during the 1980s encouraged banks to loosen underwriting standards and monitor borrowing firms less diligently, enabling borrowers to take on greater risk and making banks more vulnerable to the effects of economic downturns.

This perspective on the U.S. banking crisis not only suggests a relationship between market power and bank risk, it may also imply a relationship between market power and loan interest rates that conflicts with standard microeconomic intuition. Increased competition may necessitate higher interest rates to compensate banks for

\footnotetext{
${ }^{1}$ Deposit figures are reported in inflation adjusted 1992 dollars. All bank failure data pertain to commercial banks covered by the Bank Insurance Fund and are derived from information reported in the Federal Deposit Insurance Corporation's Historical Statistics on Banking.
} 
greater borrower risk. This paper examines the interaction between bank market power, loan interest rates, and bank risk in a model of lending characterized by overlapping moral hazard problems between borrowers and banks, and between banks and a government guarantor of bank deposits.

A moral hazard problem between banks and borrowers arises from the contract form of a bank loan under which the interest rate paid by a borrower is fixed when the loan is made. Given such a debt contract, a borrower may increase the riskiness of its investments to obtain higher returns net of interest expenses that more than compensate for a greater likelihood of failure. To mitigate this moral hazard problem, banks monitor and impose collateral requirements on borrowers.

Similarly, banks have an incentive to make risky loans in exchange for high returns because they raise the majority of their funds through debt contracts with depositors. By allowing banks to become highly leveraged, deposit insurance exacerbates this moral hazard problem. To prevent excessive risk-taking by banks, regulators impose restrictions on bank activities, require banks to issue equity capital, and continually supervise banks.

In our analysis of market power and interest rates, we show that the canonical positive relationship breaks down when bank moral hazard with respect to the government guarantor of deposits is weak, but firm moral hazard with respect to banks is strong. In a competitive lending environment, strong incentives for firms to take on risk determine the equilibrium; firms invest in high-risk projects, banks are compensated for the higher likelihood of loan defaults with relatively high interest rates, and banks do not attempt to prevent unsafe investments through monitoring. In contrast, in a monopolistic lending environment, the bank's weak moral hazard leads to a more conservative equilibrium characterized by a lower interest rate, less risk-taking behavior by firms, and greater monitoring by the bank. For all other configurations 
of the overlapping moral hazard problem, the market power/interest rate relationship is positive.

These results indicate that the direction of the empirical relationship between market power and interest rates may depend on business cycle conditions and the industry focus of bank lending. Firm moral hazard is likely to be greatest during economic recessions when the return on safe investment projects may be particularly low. Assuming that regulatory oversight minimizes bank moral hazard, measures of market power should tend to be positively correlated with loan interest rates during times of economic expansion and negatively correlated with interest rates during recessionary periods. Similarly, some borrowers, such as small businesses with limited access to safe investments, may always have a high degree of moral hazard. Therefore, we might expect to observe a negative relationship between interest rates and concentration among banks specializing in lending to these borrowers.

Although no empirical research examines the interest rate/market power relationship over the business cycle, several studies investigate this relationship in crosssectional settings. In a study of lending to small businesses, Petersen and Rajan (1995) find that the market power/interest rate relationship is negative for young firms and positive for older firms. They argue that these results are consistent with a dynamic model of lending relationships. Our model suggests an alternative explanation that follows almost immediately from Diamond's (1991) observation that young firms are likely to have strong moral hazard because they have limited reputations. Given Diamond's assertion, if banks have weak moral hazard, the market for loans to young firms is precisely the type of market in which our model predicts a negative market power/interest relationship. Our model predicts the usual positive market power/interest rate relationship for older firms, since they have reputations that weaken their moral hazard. 
Studies by Berger and Hannan (1989), and Hannan (1991, 1997) analyze the interest rate/market power relationship using bank balance sheet data. Operating under the assumption that high interest rates reflect market power, these studies interpret positive correlations between interest rates and concentration measures such as the Herfindahl Index as evidence that concentration generates market power. Our results indicate that because market power may actually lead to lower interest rates, such tests may not fully capture the role of market concentration in determining market power. ${ }^{2}$

In our analysis of market power and bank risk, we find that the strength of the bank's moral hazard with respect to the government guarantor determines the direction of the relationship. This result follows intuitively from the notion that market power enables banks to better control the behavior of borrowers through control over interest rates. A negative relationship between market power and bank risk arises for relatively conservative banks because these banks prefer low risk equilibria and are able to choose interest rates to ensure that such equilibria arise. Similarly, we find a weakly positive market power/bank risk relationship for banks with relatively high moral hazard that prefer high-risk equilibria.

Two other papers directly examine the relationship between market power and bank risk. Keeley (1990) abstracts from bank monitoring and firm investment decisions, and focuses on the effect of charter value on bank risk. Because market power creates charter value and charter value reduces banks' incentives to take risks, he finds a negative market power/bank risk relationship. Caminal and Matutes (1997)

\footnotetext{
${ }^{2}$ Shaffer (1999) articulates a related point about the relationship between lending market concentration (as distinct from market power) and interest rates. He argues that when the number of potential lenders in a market is large, adverse selection problems among borrowers increase, leading to a positive correlation between the number of banks in a market and the interest rate charged on loans. However, because Schaffer assumes that entry - or the threat of entry - ensures that banks make no monopoly profits, this analysis does not shed light on the relationship between market power and interest rates.
} 
include bank monitoring and firm investment decisions in their model, however, in equilibrium these actions only indirectly influence bank risk through their effects on equilibrium loan sizes. Carminal and Matutes find that banks with market power control firm moral hazard through monitoring whereas competitive banks control moral hazard by making smaller loans. Because larger loans are more sensitive to aggregate shocks than smaller loans, they find a positive market power/bank risk relationship.

We model bank lending as a two-stage, imperfect information game between a bank and a firm. Section 2 describes this model. Section 3 examines the equilibrium bank monitoring and firm investment strategies given a loan interest rate. Section 4 solves for equilibrium interest rates under two simple lending market structures: monopoly and perfect competition. The relationship between market structure, moral hazard, and bank risk is examined in Section 5. Section 6 concludes with a reexamination of the 1980s banking crisis in light of our model. Proofs of all lemmas are provided in the appendix.

\section{The Model}

\section{$2.1 \quad$ Players}

A profit maximizing firm has access to two different investment projects, a safe project and an unsafe project. Each project requires $\$ 1$ of investment capital. Denote the firm's probabilities of choosing the safe and the unsafe project by $p_{s}$ and $1-p_{s}$ respectively. The unsafe project pays $u$ in the future with probability $\theta$, and 0 with probability $1-\theta$. The safe project pays $s$ with certainty.

The relationship between the distribution of project returns and the risk-free interest rate $r_{f}$ is governed by the following assumption. 
Assumption $10<s-r_{f}<\theta\left(u-r_{f}\right)$.

The lower bound imposed on $s-r_{f}$ ensures that investment in the safe technology is socially desirable. ${ }^{3}$ The upper bound states that in the absence of monitoring by the bank, the firm always has an incentive to take on risk.

A profit maximizing bank holds capital $k$ and collects deposits $1-k$ in order to lend $\$ 1$ of investment funds to the firm at the interest rate $r$. The level of $k$ is fixed and is set by an outside regulator before the game begins. Deposits are insured, so that if the bank fails an outside insurance fund (the Federal Deposit Insurance Corporation or FDIC) repays depositors. The price of deposit insurance is fixed. Without loss of generality, we assume the price of deposit insurance is zero.

To abstract from issues related to portfolio diversification, we assume that the bank can make only one loan to a single firm. This assumption is common in the theoretical literature on moral hazard problems in bank lending. See, for example, Boyd, Chang and Smith (1998). It is equivalent to assuming that a bank lends to several firms but that the returns on the risky investment projects available to those firms are highly correlated. Such a situation is most likely to arise when a bank specializes in lending to a narrow industry or geographic market.

The bank may monitor the investment activities of the firm with some probability $p_{m}$. Monitoring allows the bank to recall the loan principle if the firm invests in an unsafe project. ${ }^{4}$ The present discounted cost of monitoring is $m$.

We place the following restriction on $m, k$, and the distribution of payoffs:

Assumption $2 m<(1-\theta) k r_{f}<\theta u$.

\footnotetext{
${ }^{3}$ Assumption 1 could be easily modified to incorporate exogenous firm collateral or reputation. However since we allow flexibility in the extent of the firm's moral hazard, such extensions would needlessly complicate the exposition.

${ }^{4}$ Relaxing the assumption that monitoring allows full recovery of the loan when an unsafe project is detected in no way changes the nature of our results.
} 
This assumption is a necessary condition for monitoring to occur with positive probability over some range of interest rates. It states that the expected loss in capital to a bank that lends to a firm undertaking an unsafe investment is larger than the cost of monitoring a loan, however, the bank's capital requirement is not so high that it never has an incentive to take advantage of deposit insurance.

\subsection{Timing}

The game between the bank and the firm has two stages. The first stage, shown in Figure 1, models the product market structure. We consider two simple structures. In the first (panel (a)), banks are assumed to have monopoly power over loan customers. The bank chooses an interest rate to offer the firm and the firm then decides whether to accept or reject the loan. If the loan is rejected the firm is liquidated.

In the second structure (panel (b)), banks are assumed to compete for loan customers in a perfectly competitive lending market. In a competitive equilibrium there should be no incentive for banks to enter or exit, which implies that the firm's profits attain a maximum given the constraint that the bank earns zero economic rents. We model a competitive lending environment directly by assuming that the firm offers the bank an interest rate. The bank must either accept or reject the offer, and has no opportunity to renegotiate the terms of the loan. If the bank rejects the firm's offer, it must invest it's capital and deposits in the risk-free bond.

If the bank and the firm agree to write a debt contract in stage one, play proceeds to stage two, shown in Figure 2. This subgame models the bank's monitoring decision and the firm's investment decision. Following Besanko and Kanatas (1993), we assume the bank cannot commit to monitor the firm. ${ }^{5}$ That is, the bank's monitoring decision

\footnotetext{
${ }^{5}$ This assumption contrasts with a large body of previous work by Diamond (1991), John, John and Saunders (1994), Boyd et al. (1998), Caminal and Matutes (1997), and others. This research
} 


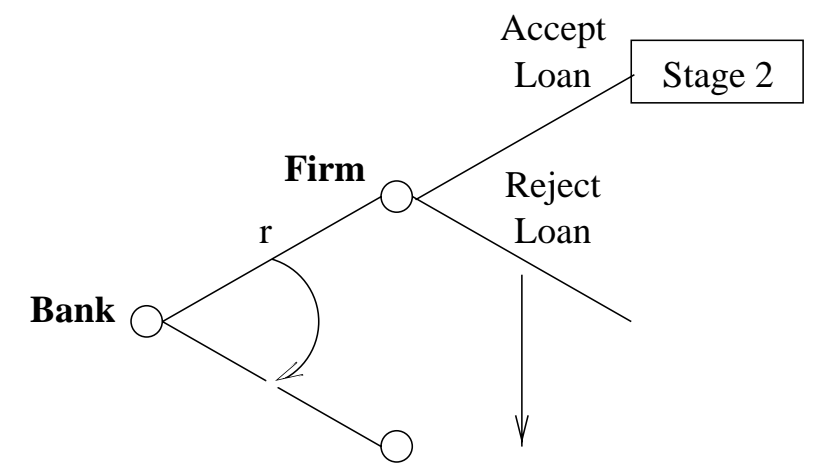

(a) Monopoly: bank offers an interest rate.

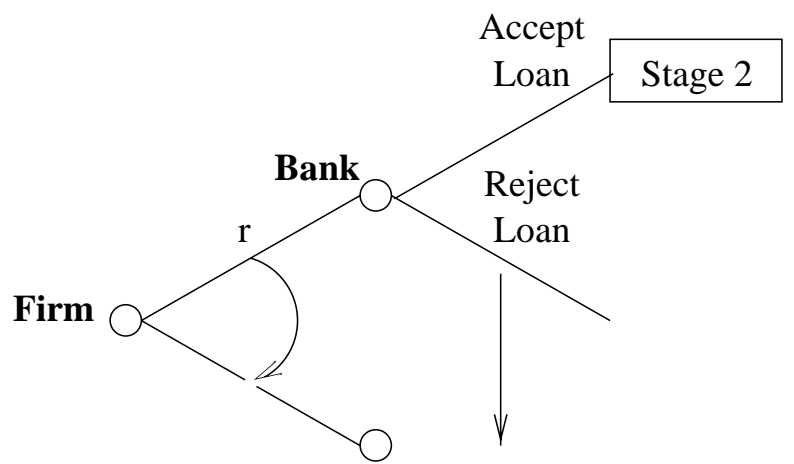

(b) Competition: firm offers an interest rate.

Figure 1: Timing in two interest rate setting games.

is not observed by the firm before it makes its investment decision. After the firm chooses an investment, a bank that monitors observes the investment decision and withdraws the loan if the unsafe project is chosen. In this case the bank invests in the risk-free bond and the firm is liquidated. If the bank does not withdraw the loan, then the firm privately observes the outcome of its investment and decides whether to pay back the loan. If the loan is paid back, the game ends. If the loan is not paid back, the firm is liquidated and both the bank and firm receive nothing. We assume liquidation is costly so that the firm repays debt whenever possible.

either assumes that firms can observe bank monitoring actions before investment decisions are made, or that banks can directly control firms' investment decisions. Both these assumptions imply that banks can commit to monitoring strategies. Our assumption is most appropriate in environments where monitoring resources are scarce and where banks have some flexibility in determining how strictly they enforce the terms of the contracts they write. 


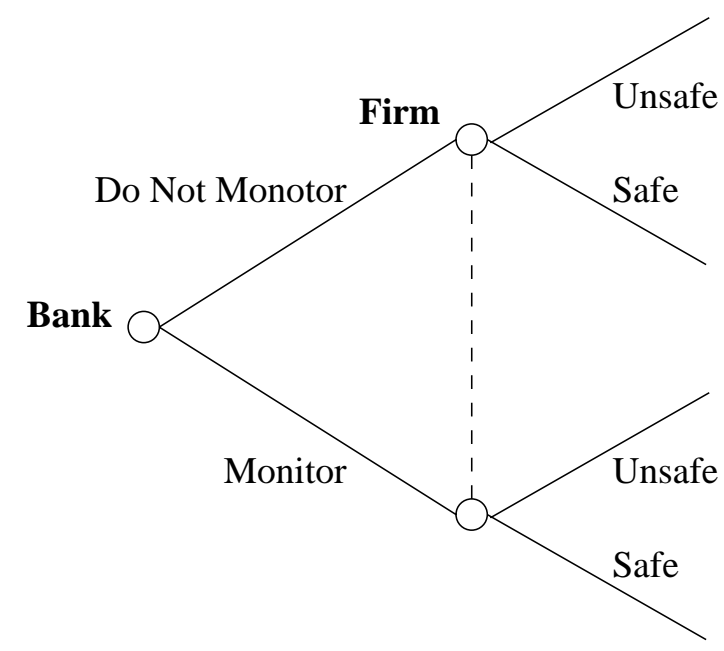

Figure 2: Timing in the monitoring/investment game.

\section{The Monitoring/Investment Game}

Since the firm's investment decision and the bank's monitoring decision are made after a loan is accepted at a given interest rate, we can analyze these decisions without first considering the process through which the interest rate is set. In this section, we discuss the monitoring and investment strategies available to the bank and the firm, and show how the equilibrium strategies depend on the interest rate of the loan.

If the firm facing interest rate $r$ chooses a safe investment technology, its future profit is

$$
\pi_{f}^{s}=s-r
$$

If the unsafe project is chosen, the firm's expected profit is

$$
\pi_{f}^{u}=\left(1-p_{m}\right) \theta(u-r)
$$

Comparing the two profit functions, we see that for a fixed monitoring probability the profit difference between choosing the unsafe project over the safe project increases 
with the interest rate. Put another way, the firm's option value of default, $(1-\theta) r$, is an increasing function of $r$. If $r>s$ the firm chooses the unsafe project even if the bank is certain to recall its loan. When $p_{m}=1$, Assumption 1 guarantees that the firm will choose the unsafe project no matter what interest rate is charged.

If the bank does not monitor the loan, its expected profit net of its opportunity cost of equity capital is

$$
\pi_{b}^{n m}=p_{s}\left(r-r_{f}\right)+\left(1-p_{s}\right) \theta\left(r-r_{f}\right)-\left(1-p_{s}\right)(1-\theta) k r_{f}
$$

Should the bank decide to monitor the loan, the bank's expected profit is

$$
\pi_{b}^{m}=p_{s}\left(r-r_{f}\right)-m
$$

By comparing the two bank profit functions, it is straightforward to show that for very high interest rates the return from a repaid loan is so great that the bank never has an incentive to monitor the firm. This critical interest rate is

$$
\tilde{r}=r_{f}+\frac{1-\theta}{\theta} k r_{f}-\frac{m}{\theta} .
$$

If $r<\tilde{r}$, the bank's monitoring decision depends on the expected behavior of the firm. When $p_{s}$ is high, the bank has relatively little incentive to monitor the loan since the probability of default $\left(p_{s}(1-\theta)\right)$ is low. If $p_{s}$ is low and the bank cannot extract high returns when an unsafe project pays off, the bank has an incentive to protect itself from default through monitoring.

If $s<r<\tilde{r}$ then the loan must be recalled, because the bank finds it most profitable to monitor unsafe loans but the firm is never able to profitably undertake a safe project. This case corresponds to an extreme form of credit rationing (see 
Stiglitz and Weiss 1981) that we rule out with the following assumption.

Assumption $3 \tilde{r}<s$.

The strategies of the firm and the bank are given by $p_{s}$ and $p_{m}$ respectively. The lemma below describes the mapping from the interest rate to equilibrium investment and monitoring strategies.

Lemma 1 Given Assumptions 1 through 3, for any interest rate $r$ in the range $r_{f} \leq$ $r \leq u$ there exists a unique Nash equilibrium $\left(\hat{p}_{s}, \hat{p}_{m}\right)$ such that

1. if $r<\tilde{r}$ then

$$
\hat{p}_{s}=1-\frac{m}{(1-\theta) k r_{f}-\theta\left(r-r_{f}\right)}
$$

and

$$
\hat{p}_{m}=1-\frac{s-r}{\theta(u-r)}
$$

2. if $\tilde{r} \leq r$ then $\hat{p}_{s}=0$ and $\hat{p}_{m}=0$.

Case 2 follows directly from the definition of $\tilde{r}$. Case 1 is a mixed strategy equilibrium that arises because the bank cannot commit to a monitoring strategy before the firm chooses which type of project to undertake. When $r \leq \tilde{r}$, a high probability of monitoring tends to encourage the firm to choose a safe project. However, if the firm is very likely to choose a safe project, the bank has little incentive to monitor because doing so only increases the bank's return when the firm chooses an unsafe project.

\section{Interest Rate Setting Games}

The bank's ability to extract rents from the firm is determined by the product market competition for loan customers. When the bank is a monopoly lender the firm has 
no outside financing option, so the bank sets the interest rate to maximize its profit subject to the constraint that the firm expects to break even. In contrast, in a competitive lending environment, power over setting interest rates effectively shifts from the bank to the firm. We model this case by assuming that the firm chooses $r$ to maximize its profit subject to the constraint that the bank has no incentive to exit (i.e. the bank earns nonnegative economic rents).

\subsection{Monopoly Lending}

Let $\hat{\pi}_{f}(r)$ and $\hat{\pi}_{b}(r)$ denote respectively the firm's and bank's expected profits from playing the equilibrium strategies described in Lemma 1. In setting the interest rate a monopoly bank solves

$$
\hat{r}_{m}=\underset{r_{f} \leq r \leq u}{\arg \max } \hat{\pi}_{b}(r)
$$

Assumptions 1 and 3 imply that the firm will always receive nonnegative expected profit once a loan is made, so the firm's participation constraint is not binding.

To characterize the solution to the bank's optimization problem, it is helpful to understand the shape of $\hat{\pi}_{b}(r)$. Figure 3 sketches the bank's expected second-stage equilibrium profit as a function of $r$ for a typical configuration of model parameters. In the range of mixing equilibria $(r<\tilde{r})$ bank profits are a concave function of the interest rate. In this region higher interest rates give the bank larger returns in the event that an investment project is successful. However, as shown in Lemma 1, they also coincide with a lower likelihood that the safe project will be chosen. As the interest rate rises, the negative effect of the firm's opportunistic behavior eventually outweighs the positive effect of higher interest rates on bank revenues. Denote the maximand over the concave portion of $\hat{\pi}_{b}(r)$ by $r^{*}$. 


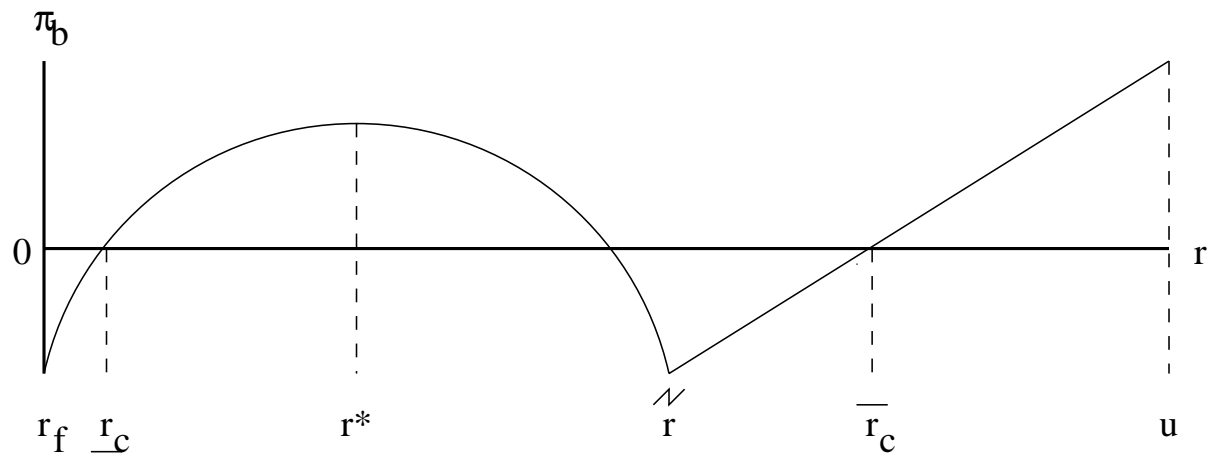

Figure 3: The bank's expected profit function.

If the bank's expected return from charging $r^{*}$ is less than its opportunity cost of capital, $k r_{f}$, the bank is never willing to extend a loan that involves monitoring in equilibrium. To ensure that $\hat{\pi}_{b}\left(r^{*}\right)>0$, we add our final parameter restriction;

\section{Assumption 4}

$$
\left(\sqrt{(1-\theta) k r_{f}}-\sqrt{m}\right)^{2}>\theta m
$$

When $r \geq \tilde{r}$ the bank has no incentive to monitor the firm and the firm is able to choose the unsafe investment project with certainty. In this region, a change in $r$ simply determines how surplus is divided between the bank and the firm. Thus, for $r \geq \tilde{r}, \hat{\pi}_{b}(r)$ is strictly increasing.

Given the shape of the bank's expected profit function we have just described, it should be clear that there exist two local maxima, one at $r^{*}$ and one at $u$. The lemma below describes these maxima.

Lemma 2 Given Assumptions 1 through 4, there exist exactly two local maximands of $\hat{\pi}_{b}(r)$ that satisfy $\hat{\pi}_{b}(r) \geq 0$ and $\hat{\pi}_{f}(r) \geq 0$. These are

$$
r^{*}=r_{f}+\frac{1-\theta}{\theta} k r_{f}-\frac{1}{\theta} \sqrt{(1-\theta) m k r_{f}} .
$$


which implies

$$
\hat{\pi}_{b}\left(r^{*}\right)=\frac{1}{\theta}\left(\sqrt{(1-\theta) k r_{f}}-\sqrt{m}\right)^{2}-m
$$

and

$$
u
$$

which implies

$$
\hat{\pi}_{b}(u)=\theta\left(u-r_{f}\right)-(1-\theta) k r_{f}
$$

Since $r^{*}<\tilde{r}$ and $u>\tilde{r}$, Lemma 1 reveals that greater risk is shifted to the FDIC when the interest rate $u$ is chosen than when $r^{*}$ is chosen. Thus, we can treat the difference

$$
M_{b}=\hat{\pi}_{b}(u)-\hat{\pi}_{b}\left(r^{*}\right)
$$

as a measure of the bank's equilibrium moral hazard with respect to the FDIC. This measure depends in an intuitive way on $k$ and $m$, the parameters of the model that directly enter the bank's profit function but do not directly affect firm profits. It is straightforward to show that $\partial M_{b} / \partial k<0$ and $\partial M_{b} / \partial m>0$. An increase in bank capital relative to insured deposits mitigates the bank moral hazard problem. Increasing $m$ makes it more costly for the bank to protect deposits, exacerbating the bank moral hazard problem.

To aid in discussing the relationship between bank moral hazard and interest rates, the following definition is useful.

Definition 1 When $M_{b}>0$, the bank has "strong moral hazard" with respect to the FDIC. Conversely, when $M_{b}<0$ the bank has "weak moral hazard" with respect to the FDIC.

Clearly, when the bank has strong moral hazard $r_{m}=u$ and when the bank has weak 
moral hazard $r_{m}=r^{*}$.

Notice that when the bank has weak moral hazard, bank profits are increasing in $k$. This counterintuitive relationship results from the strategic role of bank capital in the monitoring/investment game. Recall that once a loan is made the bank cannot commit to a monitoring strategy before the firm makes its investment decision. By raising the bank's cost of default, a higher capital requirement makes monitoring credible given the firm's original investment strategy. Thus, in the new equilibrium the firm chooses the safe project with higher probability, making the bank strictly better off.

\subsection{Competitive Lending}

In our model of a competitive lending environment, the firm solves

$$
\hat{r}_{c}=\underset{r_{f} \leq r \leq u}{\arg \max } \hat{\pi}_{f}(r) \text { such that } \hat{\pi}_{b}(r) \geq 0 .
$$

Figure 4 illustrates the firm's expected stage-two profit as a function of $r$. When $r<\tilde{r}$, the firm is indifferent between choosing the safe and the unsafe projects, so $\hat{\pi}_{f}(r)=s-r . \hat{\pi}_{f}(r)$ decreases linearly over this region. For $r \geq \tilde{r}, \hat{p}_{s}=0$ and $p_{m}=0$, so $\hat{\pi}_{f}(r)=\theta(u-r)$ which also decreases linearly. Note that when $r$ is approaching $\tilde{r}$ from below, $\hat{p}_{m}$ is increasing but drops to zero when $r=\tilde{r}$. This abrupt change in the bank's equilibrium strategy results in a discontinuous increase in the firm's expected profit.

Depending on the parameters of the model, the unique competitive equilibrium interest rate takes on one of two values. If the moral hazard problem between the firm and the bank is small relative to the bank's incentives to protect deposits from default, then the competitive interest rate lies in the range of rates generating a mixing 


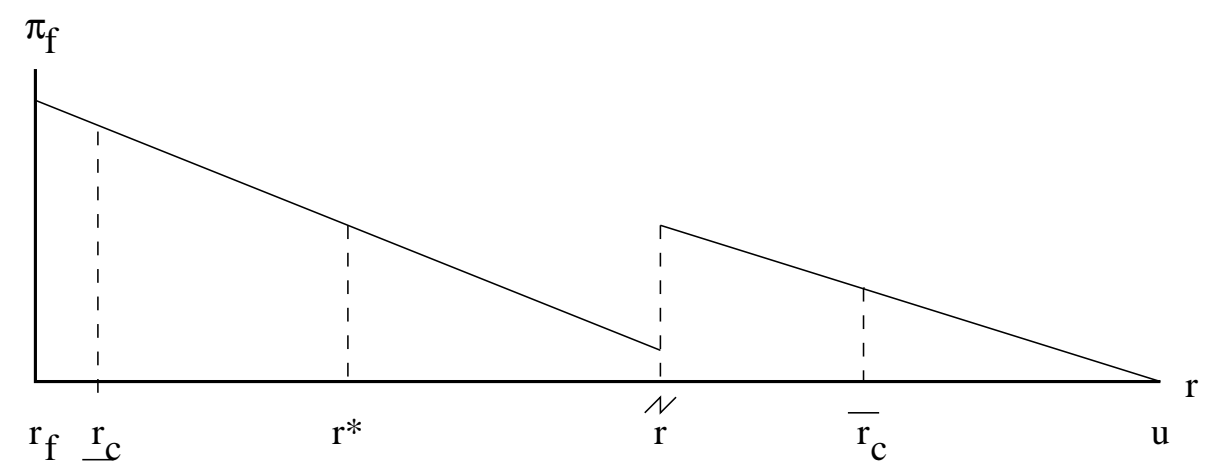

Figure 4: The firm's expected profit function.

equilibrium in monitoring and investment strategies. This interest rate is the lowest rate at which the bank can make non-negative economic profits and is denoted $\underline{r}_{c}$. If the moral hazard problem between the firm and the bank is relatively large, then the firm prefers an equilibrium involving no monitoring. The corresponding interest rate, $\bar{r}_{c}$, is the rate above $\tilde{r}$ at which the bank earns zero economic profits. These conclusions are formalized in the lemma below.

Lemma 3 Given Assumptions 1 through 4, there exist exactly two local maximands of $\hat{\pi}_{f}(r)$ that satisfy $\hat{\pi}_{f}(r) \geq 0$ and $\hat{\pi}_{b}(r) \geq 0$. These are

$$
\underline{r}_{c}=r_{f}+\frac{1-\theta}{2 \theta}\left(\left(k r_{f}-m\right)-\sqrt{\left(k r_{f}-m\right)^{2}-\frac{4 \theta}{1-\theta} k r_{f} m}\right)
$$

which implies

$$
\hat{\pi}_{f}\left(\underline{r}_{c}\right)=s-\underline{r}_{c},
$$

and

$$
\bar{r}_{c}=r_{f}+\frac{1-\theta}{\theta} k r_{f}
$$

which implies

$$
\hat{\pi}_{f}\left(\bar{r}_{c}\right)=\theta\left(u-r_{f}\right)-(1-\theta) k r_{f} .
$$


As with the bank, we can regard the difference

$$
M_{f}=\hat{\pi}_{f}\left(\bar{r}_{c}\right)-\hat{\pi}_{f}\left(\underline{r}_{c}\right)
$$

as a measure of the firm's moral hazard. When $M_{f}$ is positive the firm prefers $\bar{r}_{c}$. By Lemma 1 , at $\bar{r}_{c}, \hat{p}_{s}=0$. The firm shifts risk to the bank and the bank in turn shifts risk to the FDIC. When $M_{f}$ is negative the firm prefers $\underline{r}_{c}$. At $\underline{r}_{c}, \hat{p}_{s}>0$. The firm

shifts less risk to the bank, and the bank has a greater incentive to protect deposits through monitoring. Thus, $M_{f}$ captures the firm's incentive to choose an interest rate that shifts risk to the bank directly, and shifts risk to the FDIC indirectly. It can be shown that $\partial M_{f} / \partial u>0$ and $\partial M_{f} / \partial s<0$. Thus, as we should expect, the firm's moral hazard incentive is increasing in the gap between payoffs from the unsafe and the safe investment projects.

The following definition will aid in the exposition that follows.

Definition 2 When $M_{f}>0$, the firm has "strong moral hazard" with respect to the bank. Conversely, when $M_{f}<0$ the firm has "weak moral hazard" with respect to the bank.

Clearly, when the firm has weak moral hazard $r_{c}=\underline{r}_{c}$ and when the firm has strong moral hazard $r_{c}=\bar{r}_{c}$.

\subsection{Equilibrium Interest Rates}

Lemmas 2 and 3 and the easily verified inequalities $\underline{r}_{c}<r^{*}$ and $\bar{r}_{c}<u$ imply Proposition 1 below. This proposition describes the equilibrium relationship between bank and firm moral hazard, market structure, and the equilibrium interest rate. 
Proposition 1 If the bank has weak moral hazard and the firm has strong moral hazard, then $r_{m}<r_{c}$, otherwise $r_{c}<r_{m}$.

The surprising implication of Proposition 1 is that under some circumstances the monopoly interest rate may actually be lower than the competitive interest rate. The explanation for this result is instructive. In a competitive lending environment, control over setting interest rates effectively rests with the firm, whereas in a monopolistic environment control rests with the bank. Thus, under competition, the firm's incentives to take on risk determine the equilibrium interest rate, while under monopoly the bank's risk-taking incentives are more important.

A firm with strong moral hazard relative to the bank can obtain high expected profit by investing in the unsafe project. However, if the bank monitors the firm it will recall the loan before the unsafe investment can be made. Monitoring is prevented when $r$ so high that the bank is unwilling to forgo its expected interest payment by recalling the loan. A firm with strong moral hazard prefers such an equilibrium to a lower interest rate equilibrium in which monitoring occurs with positive probability. In a competitive lending environment the firm will only accept a loan from a bank offering an interest rate high enough to credibly guarantee that it will not be monitored.

A bank with weak moral hazard with respect to the FDIC has a relatively strong incentive to prevent default. The bank knows that in the absence of a change in its monitoring strategy, a higher interest rate increases the firm's incentive to invest in the unsafe project. The bank prefers a relatively low interest rate at which the firm can be induced to choose the safe project with positive probability to a high interest rate at which the firm chooses the unsafe project. In a monopoly setting, the bank sets $r$ low enough to guarantee that a low risk equilibria occurs. 


\section{Market Structure and Default Risk}

The ex ante probability that the firm defaults on a bank loan is

$$
R=(1-\theta)\left(1-p_{s}\right)\left(1-p_{m}\right)
$$

Because we assume that the bank makes only one loan (i.e. its loan portfolio is not diversified), $R$ also captures the probability that the bank fails, forcing the FDIC to repay depositors.

Figure 5 illustrates the relationship between $r$ and default risk. A direct consequence of Lemma 1 is that when $r<\tilde{r}$, default risk is locally decreasing in $r$. Even though higher interest rates exacerbate the moral hazard problem of the firm, higher interest rates do not imply greater risk to the deposit insurance fund. As $r$ rises the bank's marginal return from monitoring rises as well. When $r<\tilde{r}, p_{m}$ increases with $r$ faster than $p_{s}$ declines, so risk is negatively related to $r$. A discontinuity in the risk function occurs at $\tilde{r}$. When $r$ reaches $\tilde{r}$ the expected return to the bank from a loan invested in a risky project is larger than the return from recalling a monitored loan. At this point, the bank stops mixing between the monitoring and no monitoring strategies, and the firm stops mixing between the safe and unsafe investment strategies. When $r \geq \tilde{r}$ neither player takes action to protect deposits.

Since the probability of default is not monotonic in the interest rate, and since market power may result in either a higher or a lower equilibrium interest rate, we cannot unambiguously conclude that one market structure poses less risk to deposit insurance than another. Rather the relative safety of competitive and monopolistic lending markets depends on the degree of bank and firm moral hazard. Proposition 2 describes the relationship between our earlier measures of moral hazard and 


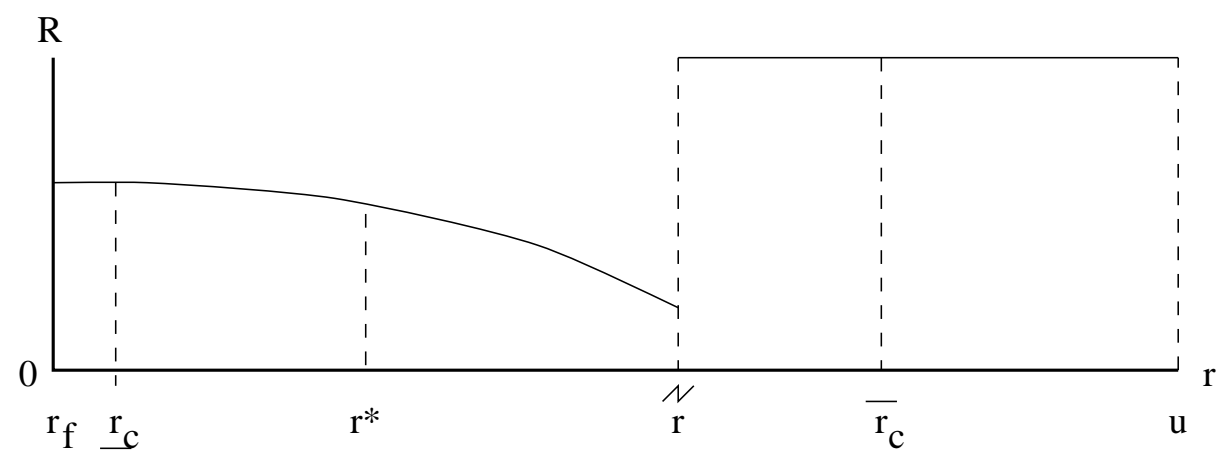

Figure 5: Equilibrium default risk as a function of the interest rate.

equilibrium bank risk.

Proposition 2 Let $\underline{R}_{c}$ and $\bar{R}_{c}$ respectively denote competitive equilibrium bank risk when the firm has weak and strong moral hazard, and let $\underline{R}_{m}$ and $\bar{R}_{m}$ respectively denote monopoly equilibrium bank risk when the bank has weak and strong moral hazard. $\underline{R}_{m}<\underline{R}_{c}<\bar{R}_{c}=\bar{R}_{m}$.

The proof of this proposition is straightforward, and follows directly from Proposition 1 and the shape of the default risk function implied by Lemma 1 and illustrated in Figure 5 .

When bank moral hazard is weak, competition increases bank risk in one of two ways. If the firm has weak moral hazard, competition bids down interest rates. At the lower competitive interest rate, the bank has less incentive to monitor the firm because (1) the firm has less incentive to undertake the risky project, and (2) the expected loss to the bank from allowing the firm to default is lower. In equilibrium, the firm chooses the safe project with higher probability, but the bank monitors with lower probability. The latter effect dominates and bank risk increases. Alternatively, as shown in Proposition 1, when the bank has weak moral hazard and the firm has strong moral hazard, competition results in a higher equilibrium interest rate than 
monopoly. In this case, the firm has such a strong incentive to invest in the unsafe project that it is willing to pay the bank an interest rate high enough to ensure that it has no incentive to monitor. In this competitive equilibrium, the firm chooses the unsafe project with certainty and the bank does not monitor.

As discussed in the introduction, an inverse relationship between market power and bank risk is also suggested by Keeley (1990). It is important to note that Keeley's explanation for this relationship is very different from our own. In Keeley's model, market power increases banks' expected future profits from remaining in business, giving them an greater incentive to reduce current risk. In our model, market power does not change banks' incentives, rather it enhances a conservative bank's ability to reduce risk through interest rate setting and monitoring.

When bank moral hazard is strong, a monopoly bank prefers to charge a very high interest rate even though this interest rate leads to high bank risk. In this case competition, by bidding down interest rates, may actually reduce bank risk. This result is consistent with theoretical research on universal banking by John et al. (1994) and Boyd et al. (1998). ${ }^{6}$ This literature shows that allowing banks that have an incentive to shift risk to the FDIC to participate in the benefits of firm risktaking through direct equity claims on firm profits may induce banks to increase risk. Proposition 2 shows that insofar as market power allows banks with strong moral hazard to participate in the upside benefits of firm risk-taking by charging higher interest rates, market power also leads to greater bank risk.

\footnotetext{
${ }^{6}$ Universal banks are banks that may invest directly in commercial enterprises. In the United States, this activity is prohibited by the Glass-Steagall Act of 1933 .
} 


\section{The 1980s Banking Crisis Reconsidered}

Volatile energy, real estate, and agriculture prices led to severe regional recessions throughout the United States during the 1980s and early 1990s. While such recessions were not new, the banking crisis associated with them had no precedent in the years following World War II. The theoretical model developed in this paper can help explain the structural causes of this crisis. Our explanation relies on two intuitive assumptions. First, regulatory oversight and capital requirements are sufficient to moderate banks' incentives to shift risk to the FDIC (i.e. banks have weak moral hazard). Second, firms' incentives to shift risk to banks are greatest during economic recessions (i.e. firms have strong moral hazard during recessions and weak moral hazards during expansions).

Given these assumptions our model tells the following story. Prior to the 1980s banks with monopoly power were able to charge borrowers moderate interest rates and guarantee low risk equilibria during both expansions and recessions. Interest rates were high enough to provide banks with economic rents, but were low enough so that banks monitored firms to limit excessive risk-taking. By the middle 1980s, increased competition among banks and between banks and other financial institutions such as Savings and Loans and finance companies had eroded banks' bargaining power vis-a-vis borrowers. During economic expansions, banks had to accept lower loan interest rates and lower profits. During recessions, firms with strong incentives to undertake risky investment projects were willing to pay high interest rates to ensure that they would not be closely monitored by banks. Without market power, banks had no choice but to accept these high interest rate/high risk equilibria. As a result, during the recessions of the 1980s, banks monitored borrowers less intensively and borrower risk-taking increased. 
Since 1993 the United States has enjoyed a protracted economic expansion and bank failure rates have returned to their low pre-1980s levels. This decline in failures is consistent with our view that in a competitive lending environment bank risk is more highly correlated with the business cycle than in a monopolistic setting. Ominously, this view predicts that bank failure rates are likely to rise again during future economic downturns. 


\section{A Proof of Lemma 1}

Assumptions 1 and 2 imply that when $r<\tilde{r}$ no weakly dominated pure strategy exists for either the firm or the bank. Therefore, there exists at least one mixed strategy Nash equilibrium. Firm indifference between the safe and unsafe project implies

$$
s-r=\theta(u-r)\left(1-p_{m}\right) .
$$

Bank indifference between monitoring and not monitoring implies

$$
\left(1-p_{s}\right) \theta\left(r-r_{f}\right)-\left(1-p_{s}\right)(1-\theta) k r_{f}=-m .
$$

The unique solution to these two conditions is $\left(\hat{p}_{s}, \hat{p}_{m}\right)$.

By Assumptions 2 and 3, when $r \geq \tilde{r}$ bank monitoring is weakly dominated by not monitoring. Therefore $\hat{p}_{m}=1$ and the firm's best response is $\hat{p}_{s}=0$.

\section{B Proof of Lemma 2}

Lemma 2 describes the local maxima associated with (1). When $r \leq \tilde{r}$, the bank is indifferent between monitoring and not monitoring, so stage two equilibrium bank profit can be written $\pi_{b}(r)=\left(r-r_{f}\right) \hat{p}_{s}-m$ where $\hat{p}_{s}$ is the equilibrium stage two monitoring probability defined in Case 1 of Lemma 1. Substitution gives us,

$$
\pi_{b}(r)=\left(r-r_{f}\right)\left(1-\frac{m}{(1-\theta) k r_{f}-\theta\left(r-r_{f}\right)}\right)-m .
$$

Twice differentiating (3) with respect to $r$ yields

$$
-2\left(\frac{m \theta}{\left((1-\theta) k r_{f}-\theta\left(r-r_{f}\right)\right)^{2}}+\frac{\theta^{2} m\left(r-r_{f}\right)}{\left((1-\theta) k r_{f}-\theta\left(r-r_{f}\right)\right)^{3}}\right) .
$$

By inspection this expression is strictly less than zero for $r_{f}<r \leq \tilde{r}$ so $\pi_{b}(r)$ is strictly concave over this region. Since

$$
\pi_{b}\left(r_{f}\right)=\pi_{b}(\tilde{r})=-m
$$

a unique interior maximum exists. Solving the first order conditions yields $r^{*}$. Assumption 4 guarantees that $k$ is sufficiently high to ensure that banks earn positive economic profits at $r^{*}$. To see this, evaluate $\hat{\pi}_{b}(r)$ at $r^{*}$, set it greater than or equal to zero, and rearrange terms.

When $r>\tilde{r}$, stage two equilibrium bank profit is

$$
\pi_{b}(r)=\theta\left(r-r_{f}\right)-(1-\theta) k r_{f}
$$


Clearly the unique maximand of this linearly increasing function is $u$.

\section{Proof of Lemma 3}

Lemma 3 describes the local maxima associated with (2). When $r \leq \tilde{r}$, stage two equilibrium firm profit is

$$
\pi_{f}(r)=s-r
$$

which clearly decreases in $r$. Therefore the local maximand is the lowest value of $r$ such that $\pi_{b}(r) \geq 0$. As shown in the proof of Lemma 2, assumption 4 ensures that $\pi_{b}\left(r^{*}\right)>0$. This fact along with the strict concavity of $\pi_{b}(r)$ over the interval $\left[r_{f}, \tilde{r}\right]$ implies that there exists a nonempty, compact interval $\rho \subset\left[r_{f}, \tilde{r}\right]$ who's elements satisfy the bank's participation constraint. Therefore, $\underline{r}_{c}=\min (\rho)$, and is obtained by finding the smaller value of the two quadratic roots of $r$ that set (3) equal to 0 .

When $r>\tilde{r}$, stage two equilibrium firm profit is

$$
\pi_{f}(r)=\theta(u-r)
$$

which decreases in $r$. Since (4) increases in $r, \bar{r}_{c}$ is the unique value of $r$ that sets (4) equal to 0 . Assumptions 2 and 3 guarantees that this $r$ exists. 


\section{References}

Berger, A. and Hannan, T.: 1989, The price-concentration relationship in banking, Review of Economics and Statistics 71, 291-299.

Besanko, D. and Kanatas, G.: 1993, Credit market equilibrium with bank monitoring and moral hazard, Review of Financial Studies 6(1), 213-232.

Boyd, J. H., Chang, C. and Smith, B. D.: 1998, Moral hazard under commercial and universal banking, Journal of Money, Credit, and Banking 30(3), 426-467.

Caminal, R. and Matutes, C.: 1997, Bank solvency, market structure, and monitoring incentives, Industrial Organization Discussion Paper Series 1665, Centre for Economic Policy Research.

Diamond, D. W.: 1991, Monitoring and reputation: The choice between bank loans and directly placed debt, Journal of Political Economy 99(4), 689-721.

Federal Deposit Insurance Corporation: 1997, History of the 1980s - Lessons for the Future, Vol. 1, FDIC Public Information Center.

Hannan, T. H.: 1991, Bank commercial loan markets and the role of market structure: Evidence from surveys of commercial lending, Journal of Banking and Finance 15, 133-149.

Hannan, T. H.: 1997, Market share inequality, the number of competitors, and the HHI: An examination of bank pricing, Review of Industrial Organization 12(1), 23-35.

John, K., John, T. A. and Saunders, A.: 1994, Universal banking and firm risk-taking, Journal of Banking and Finance 18, 307-323.

Keeley, M. C.: 1990, Deposit insurance, risk, and market power in banking, American Economic Review 80(5), 1183-1200.

Petersen, M. A. and Rajan, R. G.: 1995, The effect of credit market competition on lending relationships, Quarterly Journal of Economics 110(2), 407-443.

Shaffer, S.: 1999, Adverse selection, market structure, and competitive pricing in bank lending, Proceedings of 35th Annual Conference on Bank Structure and Competition. Forthcoming.

Stiglitz, J. E. and Weiss, A.: 1981, Credit rationing in markets with imperfect information, American Economic Review 71(3), 393-410. 